\title{
ВИМОГИ ДО АВТЕНТИЧНИХ МАТЕРІАЛІВ ТА ЇХ ЗНАЧЕННЯ У ФОРМУВАННІ ІНШОМОВНОЇ КОМПЕТЕНЦІЇ НА ЗАНЯТТЯХ ЗІ СТУДЕНТАМИ НЕМОВНИХ ФАКУЛЬТЕТІВ ЗАКЛАДІВ ВИЩОЇ ОСВІТИ
}

\author{
Роснко Л. В. \\ старший викладач кафедри іноземних мов \\ Київський національний університет технологій $і$ дизайну \\ вул. Немировича-Данченка, 2, Київ, Украӥна \\ orcid.org/0000-0002-6794-0051 \\ lroyenko@gmail.com
}

\begin{abstract}
Ключові слова: автентичні тексти, иляхи адаптації автентичних матеріалів, аналіз потреб студентів, рівень складності автентичних матеріалів, недоліки та переваги використання автентичних матеріалів.
\end{abstract}

У статті проаналізовано головні вимоги до використання автентичних матеріалів (текстів) під час занять 3 англійської мови зі студентами немовних факультетів 3ВО. Здійснено аналіз визначення лінгвістівнауковців щодо того, які тексти іноземною мовою можуть вважатися автентичними. Загалом, автентичними доцільно вважати тексти, що запозичені із комунікативної практики носіїв мови і призначені для сприйняття носіями такої мови. У статті значна увага приділяється важливості використання автентичних матеріалів як джерела реальної мови у реальному життєвому контексті. Здійснено аналіз аспектів актуальності і доречності використання автентичних матеріалів на заняттях 3 іноземної мови фахового спрямування, також зазначено переваги та труднощі використання автентичних матеріалів на заняттях зі студентами. У дослідженні описані основні критерії, за якими викладач має здійснювати відбір автентичних матеріалів з навчальною метою. Серед найважливіших критеріїв зазначено культурний аспект, довжину тексту, складність, співвідношення вже відомих та нових слів в автентичному тексті. Окреслено головні шляхи та методи адаптації автентичних матеріалів до потреб студентів, де може здійснюватися розширення тексту, видалення певних елементів або можуть бути внесені зміни у завдання до тексту. Оцінювання автентичних текстів як потенційних навчальних матеріалів рекомендовано здійснювати, використовуючи CATALYST аналіз, який стосується аспектів відповідності матеріалів до мети заняття, доречності використання, доступності, відповідності мовного рівня підготовки студентів, наскільки матеріал $є$ цікавим, чи матеріал уже застосовувався раніше під час занять, та загальне враження викладача щодо його навчальної ефективності. Також слід звернути увагу на культурний аспект, довжину статті, кількість нової лексики. Оскільки використання поданих навчальних матеріалів має сильний мотиваційний вплив на студентів, позитивний чи негативний, у статті наголошується, що викладач повинен ставити перед собою чітку педагогічну мету, чому на занятті є доречним використання автентичних текстів. Пропонується використання онлайн-ресурсу Oxford Text Checker для перевірки рівня лексичної складності автентичних текстів та пояснюються особливості його застосування. 


\title{
THE REQUIREMENTS FOR AUTHENTIC MATERIALS AND THEIR IMPORTANCE IN FOREGN LANGUAGE COMPETENCE FORMATION IN CLASSROOMS WITH STUDENTS OF NONLINGUISTIC DEPARTMENTS OF HIGHER EDUCATIONAL ESTABLISHMENTS
}

\author{
Roienko L. V. \\ Senior Lecturer at the Foreign Languages Department \\ Kyiv National University of Technologies and Design \\ Nemyrovicha-Danchenka str., 2, Kyiv, Ukraine \\ orcid.org/0000-0002-6794-0051 \\ lroyenko@gmail.com
}

Key words: authentic texts, ways of authentic materials adaptation, students' needs analyses, level of the authentic materials' difficulty, advantages and disadvantages of authentic materials using.

\begin{abstract}
The main requirements for using authentic materials (texts) in English classes with students from non-linguistic departments of higher educational establishments have been analyzed in the article. The definitions of linguists researchers regarding the aspect which texts written in foreign language can be described as authentic have been suggested. In general, it is advisable to consider the texts authentic if they have been borrowed from the native speakers' communicative practice and are designed for the native speakers' comprehension. The main attention in the article is paid to the significance of using authentic materials as a source of real language in real-life context. The study analyzed such aspects as relevance and appropriateness of the authentic materials use in the ESP classrooms. The main criteria, with the help of which a teacher has to make choice concerning authentic materials with an educational purpose, have been described in the given research. The most important criteria include the cultural aspect, the length of the text, the difficulty of the text, the ratio between the familiar and unknown words. The main ways and methods of the authentic materials' adaptation have been outlined. The process of authentic texts' adaptation should include the following stages: evaluation of the text material, the development stage and the adaptation process itself. The evaluation of authentic texts as potential educational materials is recommended to carry out using the CATALYST analyses, which reflects such aspects as communication, educational aims, teachability, availability, level, the teacher's impression concerning its effectiveness, the students' interests and if the text has been tried and tested before. It is suggested in the given research to use the online resource Oxford Text Checker with the aim to estimate the level of lexical difficulty of the chosen authentic texts. The issue of the necessity to conduct the analyses of the students' language needs is extremely important, because the choice of authentic materials should satisfy the students' educational needs.
\end{abstract}

Постановка проблеми. Найкращий спосіб вивчити іноземну мову -спілкуватись із носіями мови, відвідати країну, де цією мовою розмовляють, і якнайбільше зануритись у місцеве мовне середовище. Тому один із дієвих способів познайомити студентів із реально вживаною англійською мовою -використовувати автентичні англомовні тести під час занять. Автентичні матеріали доступні з різних джерел масової інформації, а також наявні в широкому доступі у світовій мережі Інтернет.

Аналіз останніх досліджень і публікацій. Проблему формування іншомовної компетенції за допомогою використання автентичних матеріалів досліджували багато вітчизняних та іноземних дослідників, серед яких - Н.С. Дмітренко, I.M. Коломійчук, Т.М. Кравченко, А.М. Габовда, Ю.В. Маркобок, Г.І. Верещагін, К.В. Носонович, Г.П. Мильруд, А.Я. Ягнич, М.А. Казакова, M. Peacock, R. Senior, S. Berardo, R. Sabio, N. Norhall, S. Shepherd, R. Hereida, M.P. Breen.

По-перше, давайте розглянемо визначення терміна «автентичні матеріали». R. Sabio вважає, що автентичними можна назвати матеріали, які не створювались спеціально для студентів, які 
вивчають мову, і котрі у зв'язку з цим не написані спрощеною мовою. R. Sabio висуває точку зору, що автентичні матеріали - це тексти для читання, які написані носіями мови і опубліковані у контексті, який призначений для сприйняття такими ж носіями мови, і при цьому не бралося до уваги, як ці тексти будуть інтерпретуватись не носіями такої мови. Теми, мова, синтаксис, структура тощо підбирались саме під особливості цільової аудиторії носіїв мови і пропонуються через засоби масової інформації, які насамперед націлені на носіїв такої мови [10, с. 56].

На думку Г.І. Вороніної, автентичні тексти це тексти, запозичені 3 комунікативної практики носіїв мови [1, с. 55].

Інші висловлюють думку, що автентичні матеріали в принципі - це матеріали, що не були адаптовані жодним чином. Якщо матеріал все ще той самий по суті, але можливо був скорочений або декілька слів змінені, то тоді такі матеріали можна назвати напівавтентичними.

I.M. Коломійчук переконана, що саме автентичний текст може передати всю глибину та різноманітність іноземної мови; вважає, що в лінгвістичному аспекті автентичні тексти характеризуються своєрідністю лексики: в них має місце безліч займенників, часток, вигуків, слів з емоційним забарвленням, фразеологізмів, ідіом, мовних кліше тощо. Матеріали автентичного характеру забезпечують соціокультурну спрямованість навчання, оскільки такий текст містить інформацію про культуру країни, відображає іiі національну специфіку [2, с. 104].

C. Nuttall зазначає, що автентичні тексти можуть надзвичайно мотивувати студентів, адже вони є доказом того, що мова використовується реальними людьми у справжніх життєвих ситуаціях [7, с.172].

Проблема використання автентичних текстів під час навчання іноземної мови вже довгий час привертає увагу викладачів іноземних мов, але питання методів адаптації автентичних матеріалів ще залишає поле для подальших досліджень та ідей.

Мета статті. Мета цього дослідження - проаналізувати вимоги допідбору автентичних навчальних матеріалів (текстів для читання та опрацювання) для використання під час занять 3 дисципліни «Іноземна мова фахового спрямування» зі студентами немовних факультетів 3ВО; з'ясувати переваги та недоліки використання автентичних текстів; окреслити шляхи та методи адаптації автентичних матеріалів до потреб студентів.

Виклад основного матеріалу. Автентичні матеріали можна знайти у величезній кількості, тому певна увага має приділятись процесу їх вибору. Давайте розглянемо аспекти актуально- сті та доречності. Говорячи про актуальність, ми повинні звернути увагу на чотири важливі компоненти: культурний аспект, сучасні тенденції, інтереси та потреби студентів, а також форму їх презентації.

Культурний аспект $є$ найважливішим. Матеріал, у якому зневажаються соціальні норми i точки зору, може викликати негативну реакцію у студентів. Студенти найбільше зацікавлені у новинах сучасних тенденцій. Може бути справді корисним обговорити на заняттях теми, яким приділено багато уваги у новинах, такі як політика, мода, найновіші винаходи тощо. Автентичні матеріали, які переплітаються зі студентськими інтересами, без сумніву, є ресурсами, що гарантуватимуть увагу студентів та активізують їхню допитливість. Інтереси і потреби студентів $є$ надзвичайно важливими, і студенти хочуть відчувати, що ці потреби задовольняються.

Студенти бажають відчувати відповідність навчального матеріалу реальній життєвій або робочій ситуації. Якщо освітні потреби студентів не задовольняються, то викладач може сприйматись ними як неефективний, а студенти будуть відчувати безперспективність. Очікування і потреби студентів повинні братись до уваги й аналізуватись ще до початку заняття для того, щоб підвищити рівень задоволення студентів від заняття i гарантувати ефективність вибраного матеріалу. Проведення аналізу потреб $є$ корисним у такій ситуації, оскільки він може виявити очікування студентів. Автентичні матеріали пропонують велику перевагу над матеріалами, написаними 3 метою вивчення мови. Y.K. Michel вважає, що викладач, котрий може приймати рішення щодо вибору і розробки відповідних матеріалів для його студентів, на відміну від викладача, який покладається на вже розроблені матеріали, має більше шансів уникнути бути в «неволі» у матеріалів, які не належним чином задовольняють цілі занять. Він легко може заповнити прогалину між тим, що пропонують наявні підручники, і потребами студентів [5, с. 260].

Переваги використання автентичних матеріалів полягають у тому, що вони дають можливість студентам із вищим рівнем володіння іноземною мовою зануритись у нередаговану мову носіїв мови - мову, яка фактично використовується носіями такої мови для спілкування із такими ж носіями мови [6, с. 57].

Автентичні матеріали - контракт або лист електронної пошти - це зазвичай початкова точка для обговорення того, як спілкуватися більш ефективно. Студенти знайомляться зі словом або фразою і виявляють бажання обговорити значення $\mathrm{i}$ пов'язані із ним відтінки значень. Достовірність матеріалу робить його впливовим і вартим довіри. 
Щоб узагальнити значення переваг, можемо зазначити, що автентичні матеріали:

- допомагають підготувати студентів до спілкування у «реальному» світі, занурюють студентів у справжню мову;

- більше наближені до студентських потреб;

- скеровують студентів у напрямі мови, яка їм необхідна для висловлення у певному контексті;

- вони позитивно мотивують студентів;

- надають автентичну культурну інформацію;

- слугують підтримкою для творчого підходу у викладанні [3, с. 64].

$€$ певні недоліки під час застосування автентичних матеріалів. Найбільшим недоліком використання автентичних матеріалів $є$ те, що вони вміщують занадто багато незнайомих мовних одиниць, а це надзвичайно ускладнює сприйняття студентами іншомовного матеріалу. До того ж вони часто великі за обсягом та складні. Їх важко використовувати, тому що «реальний світ є неідеальним». Типові статті газет або журналів зазвичай не пишуться на рівні А2 або В1. Їх розуміння вимагає значно вищої підготовки від студентів. Тому ми розуміємо, що не кожна цільова аудиторія студентів може якісно опанувати такі матеріали. Також навіть якщо ми знайшли автентичний матеріал необхідного обсягу та рівня, він все одно буде вимагати додаткових пояснюючих матеріалів від викладача. Процес підготовки таких додаткових матеріалів може приносити задоволення, але якщо викладач обмежений часовими рамками, то йому доведеться шукати вже готові навчальні матеріали.

Іншим впливовим фактором $\epsilon$ доцільність онлайн-матеріалів. Автентичні онлайн-матеріали часто вміщують у собі «сюрпризи» - контент, що не $\epsilon$ прийнятним для використання під час занять зі студентами. Тому важливо, щоб матеріали пройшли перевірку, викладач переконався, що їх можна застосовувати на занятті з іноземної мови фахового спрямування. Є декілька аспектів, які варто взяти до уваги, визначаючи доцільність певних онлайн-матеріалів: культурний аспект, довжину тексту, складність, співвідношення вже відомих та нових слів.

Онлайн-матеріали, які ілюструють графічні зображення життєвих ситуацій, слід використовувати 3 обережністю. Також контент, який $є$ важким для студентів із низьким рівнем володіння мовою, буде лише ставати перешкодою в процесі оволодіння мовою. Слід уникати культурно чутливих тем, щоб не образити когось зі студентів. Якщо викладач не обізнаний, як студенти відреагують, тоді матеріал не слід використовувати взагалі. Довжина онлайн-статті є теж досить важливим аспектом. Студенти можуть втратити інтерес до заняття, якщо навчальні матеріали будуть занадто довгими, i, навпаки, занадто короткі матеріали не матимуть достатнього вмісту, щоб створити змістовне заняття. R. Sabio пропонує таку довжину онлайн-матеріалів: студенти рівня advanced - 700-800 слів, рівень intermediate - від 400 до 600 слів, рівень beginning - elementary 100-200 слів [10, с. 58].

Складність $є$ одним із найважчих факторів для визначення. Ось декілька запитань, які викладачі повинні поставити собі, намагаючись визначити рівень складності онлайн-матеріалів.

- Чи матеріал за межею розуміння студентами?

- Чи матеріал вміщує мовні конструкції, що є важкими для сприймання студентами?

- Чи лексичний рівень матеріалу відповідає наявному рівню володіння мовою студентів чи значно перевищує його?

Знайомство студентів із занадто великою кількістю нових слів може викликати швидше регрес, аніж рух уперед. Перевантаження словника може спричинити стрес і тривожність. Один зі шляхів перемогти таку проблему -подавати нові лексичні одиниці поряд з уже відомими для студентів. Студенти бачитимуть знайомі лексичні одиниці і нова лексика не буде здаватись їм занадто складною. Використовуючи автентичні матеріали, викладач повинен мати перед собою конкретну мету. Так, R. Senior вважає, що нам потрібно усвідомлювати чітку педагогічну мету: чого конкретно наші студенти мають навчитись, використовуючи такі матеріали [11, с. 71].

Матеріали, які використовуються під час занять, представляють один із головних елементів навчального процесу. Навчальні матеріали не лише підтримують навчальний процес, але вони можуть впливати, позитивно чи негативно, на мотивацію студентів. Тому процес відбору, розробки і адаптації найбільш точних матеріалів для навчання залежно від потреб студентів $є$ особливо важливим.

У зв'язку 3 цим наявні три можливі і чітко визначені шляхи адаптації фактичного матеріалу до навчальних потреб:

- оцінювання матеріалу;

- глибокий аналіз матеріалу;

- адаптація матеріалу [9].

На етапі оцінювання рекомендовано здійснити початкову оцінку, потім оцінювання деталей та практичної значимості.

Для початкового оцінювання матеріалу N. Grant пропонує CATALYST тест. Вісім літер слова CATALYST презентують вісім критеріїв, за допомогою яких ми вирішуємо, чи матеріал відповідає меті і завданням нашого заняття.

1) Комунікативність (Communicative) - чи студенти зможуть використовувати вміщені у матеріалі лексичні одиниці у подальшому спілкуванні? 
2) Відповідність меті заняття (Aims).

3) Чи матеріал доречний для викладання та зрозумілий? (Teachable).

4) Чи матеріал доступний? (Available).

5) Чи відповідного рівня? (Level).

6) Яке ваше загальне враження? (Your impression).

7) Чи виявиться матеріал цікавим для студентів? (Student interest).

8) Чи матеріал випробовувався раніше під час занять? (Tried and tested) [4, с. 88].

Викладачі можуть адаптувати автентичний матеріал до потреб їхніх студентів. При цьому дуже важливо розуміти, як цей матеріал буде сприйматися на заняттях студентами, оскільки вони головні споживачі такого контенту. Тому важливо здійснити аналіз навчальних потреб студентів.

Методи адаптації матеріалів:

Категорія «плюс»

1) Додавання - викладачі можуть додати в матеріал інші тексти.

2) Розширення - розширення текстового матеріалу, збільшуючи довжину, ускладнюючи його.

Категорія «мінус»

1) Видалення певних елементів тексту.

2) Скорочення матеріалу (викладач може скоротити тексти і речення, і таким чином зробити матеріал більш легким для сприйняття).

Категорія «нуль»

1) Викладач може внести зміни у завдання до матеріалу.

2) Викладач може змінити позицію текстів та ілюстрацій.

3) Викладач може змінити формат подачі матеріалу (вебсторінку замінити друкованим варіантом) і т. д.

Підбираючи автентичний текст з навчальною метою, дуже доречним, на наш погляд, є використання онлайн-ресурсу Oxford Text Checker [8]. Ми вставляємо вибраний нами автентичний текст у відповідне вікно, натискаємо "Check text" i отримуємо докладний аналіз такого тексту щодо його лексичної складності. Так, наприклад, давайте перевіримо ось такий уривок автентичного тексту, взятий із Інтернету про роботу компанії Sony:

"Established in July 2016 by Sony Corporation, Sony Innovation Fund engages with pioneering startups to help fuel the development of disruptive technologies and launch new businesses. In addition to investment, Sony Innovation Fund closely collaborates with the startups in which it invests, connecting them with businesses throughout Sony and its worldwide network of partners, providing guidance and advice, and collaborating with them to help achieve common success" [12].
У результаті перевірки ми можемо чітко побачити, що лексика із цього тексту належить до словникового запасу Oxford 5000, і праворуч нам показано, що в тексті наявні лексичні одиниці рівнів A1, А2, В1, В2 та С1 відповідно. Лексичні одиниці різних рівнів забарвлені різними кольорами.

Якщо натиснути опцію "Results", маємо можливість побачити кількість слів у цьому тексті, кількість речень, середню кількість слів у реченні та відсоткове співвідношення лексики різного рівня складності. Таким чином, ми можемо дізнатись, скільки лексичних одиниць належать до списку Oxford 3000, Oxford 5000, Oxford 5000, виключаючи Oxford 3000, слова категорії OPAL та які слова не потрапили у подані категорії. Проаналізувавши будь-який автентичний текст таким чином, викладач відразу розуміє рівень складності підібраного тексту і наскільки доречним буде використання такого мовного матеріалу під час навчання студентів, з огляду на їхній рівень попередньої мовної підготовки.

Також, продовжуючи роботу над текстом, викладач може створити список слів певного рівня, наприклад В2. Для цього використовуємо опцію “Activities”. У фільтрі вибираємо потрібний нам рівень (у цьому разі В2), натискаємо "Done" i перед нами з'являється наш текст із виділеними лексичними одиницями рівня В2. Якщо натиснемо опцію "Create a wordlist”, то отримаємо список слів такого рівня, який можемо скопіювати та використовувати на заняттях зі студентами. На цій вебсторінці викладач також може швидко перетворити уривок автентичного тексту у лексичну вправу, використовуючи опцію "Create an exercise" та скопіювавши створену вправу.

Висновки. Підсумовуючи матеріал, викладений вище, можемо впевнено зазначити, що автентичні тексти для студентів $\epsilon$ джерелом реальної мови, яка використовується у реальному контексті. Робота з автентичними матеріалами високо мотивує студентів, а їх розуміння дарує відчуття успіху, який мотивує до подальшого читання. Автентичні тексти відображають зміни у використанні мови, наявні різні типи текстів, які можуть бути використані для тренування різних мовних навичок, а також адаптовані до потреб студентів. Одним із джерел автентичного матеріалу може бути Інтернет із величезною кількістю доступного матеріалу. Роль викладача полягає не в тому, щоб ввести студента в оману, а у тому, щоб максимально підготувати його, озброїти необхідними мовними навичками розуміння того, як мова насправді використовується. Більше того, це дає можливість студентам побачити, як англійська мова використовується у міжнародному контексті. 


\section{ЛІТЕРАТУРА}

1. Вороніна Г.І. Організація роботи з автентичними текстами молодіжної преси у старших класах шкіл з поглибленим вивченням німецької мови. Іноземні мови у шкільництвві. 1999. № 2. С. 55-59.

2. Коломійчук I.M. Автентичні матеріали як ефективний засіб забезпечення соціокультурного спрямування процесу навчання іноземної мови. Вісник університету імені Альфреда Нобеля. Серія «Педагогіка і психологія». Педагогічні науки. 2017. № 1 (13) С. 102-105.

3. Berardo S.A. The use of authentic materials in the teaching of reading. The Reading Matrix. 2006. No. 6 (2). P. 60-67.

4. Grant N. Making the most of your textbook. London : Longman, 1987. P. 88.

5. Michel Y.K. EFL Materials - from Adoption to Adaptation: Definitional, Practical and Operational Aspects of Textbook Development by Teachers. International Journal of English and Education Vol. 7, Issue 4. 2018. P. 260-274.

6. Norhall N. Reading online. English Teaching Professional. 2010. No. 71. P. 57-58.

7. Nuttall C. Teaching Reading Skills in a foreign language. New Edition. Oxford : Heinemann. 1996. 290 p.

8. Oxford Learner's Dictionaries. Oxford Text Checker. URL: https://www.oxfordlearnersdictionaries.com/ text-checker/.

9. Shepherd S. Using authentic materials. URL: https://www.teachingenglish.org.uk/article/using-authenticmaterials.

10. Sabio R. Choosing online materials. English Teaching Professional. 2009. No. 65. P. 56-58.

11. Senior R. Authentic Responses to Authentic Materials. English Teaching Professional. 2005. No. 38. P. 71.

12. Sony Innovation Fund. URL: http://www.sonyinnovationfund.com/.

\section{REFERENCES}

1. Voronina, H.I. (1999). Orhanizatsiia roboty z avtentychnymy tekstamy molodizhnoi presy u starshykh klasakh shkil z pohlyblenym vyvchenniam nimetskoi movy [Organisation of work with youth press's authentic texts in high schools with in-depth study of German language]. Inozemni movy u shkilnytstvi [Foreign languages in schooling]. Vol. 2. P. 55-59 [in Ukrainian].

2. Kolomiichuk, I.M. (2017). Avtentychni materialy yak efektyvnyi zasib zabezpechennia sotsiokulturnoho spriamuvannia protsesu navchannia inozemnoi movy [Authentic materials as an effective way of sociocultural formation of the foreign language teaching process]. Visnyk universytetu imeni Alfreda Nobelia. Seriia "Pedahohika i psykholohiia". Pedahohichni nauky. [Alfred Nobel University Bulletin. Edition " Pedagogics and psychology". Pedagogical sciences]. Vol. 1(13). P. 102-105 [in Ukrainian].

3. Berardo, S.A. (2006). The use of authentic materials in the teaching of reading. The Reading Matrix. Vol. 6 (2), P. 60-67.

4. Grant, N. (1987). Making the most of your textbook. London: Longman, P. 88.

5. Michel, Y.K. (2018). EFL Materials - from Adoption to Adaptation: Definitional, Practical and Operational Aspects of Textbook Development by Teachers. International Journal of English and Education. Vol. 7(4). P. 260-274.

6. Norhall, N. (2010). Reading online. English Teaching Professional. Vol. 71. P. 57-58.

7. Nuttall, C. (1996). Teaching Reading Skills in a foreign language. New Edition. Oxford: Heinemann.

8. Oxford Learner's Dictionaries. Oxford Text Checker. URL: https://www.oxfordlearnersdictionaries.com/ text-checker/.

9. Shepherd, S. (2020). Using authentic materials. URL: https://www.teachingenglish.org.uk/article/usingauthentic-materials.

10. Sabio R. (2009). Choosing online materials. English Teaching Professional. Vol. 65. P. 56-58.

11. Senior, R (2005). Authentic Responses to Authentic Materials. English Teaching Professional. Vol. 38. P. 71.

12. Sony Innovation Fund. URL: http://www.sonyinnovationfund.com/. 